ANNUAL ADDRESS.*

\title{
Observations on the Sources of Hawaiian Encyrtidae (Hymenoptera).
}

\author{
BY P. H. TIMBERLAKE.
}

In 1.901 when Ashmead published his descriptions of the Hymenoptera Parasitica of the Hawaiian Islands in the Fauna Hawaiiensis, Vol. 1, Pt. 3, only five species' of Encyrtidae ${ }^{1}$ were known to occur in these Islands. Of these one species was described by Cameron in 1886 from a specimen collected by Blackburn. This species, Encyrtus insularis, belonging apparently to the new genus Bothriencyrtus, ${ }^{2}$ has not been found since and is presumably an immigrant species that failed to become established. Two other species described as new are apparently endemic and may be known in the future as Echthrogonatopus molokaiensis and Nesencyrtus kaalae, having been wrongly referred by Ashmead to Microterys and Adelencyrtus respectively. The fourth species is considered to be the common Encyrtus infelix (Embleton) incorrectly identified by Ashmead as Encyrtus fuscus (Howard) and now known to be nearly cosmopolitan. A fifth species not mentioned by Ashmead was described in 1898 by Dr. Howard as Blepyrus marsdeni, and which I have recently synonymized with Blepyrus mexicanus Howard.

In $1907 \mathrm{Mr}$. Swezey published his observations and figure of a small Encyrtid, under the name of Ageniaspis species, which he found parasitizing the larvae of Odynerus nigripennis

*The President being absent in Army service, the Vice-President gave the Annual Address.-[E.]

1 In the sense used here the Encyrtidae include only the group known as the Encyrtinae by most modern writers, to the exclusion of the Eupelmidae, Signiphoridae and Aphelinidae which have been associated with the Encyrtidae by some authorities.

2 The new genera and species mentioned will be described in an appendix to this paper.

Proc. Haw. Ent. Soc., IV, No. I, June, 1919. 
(Holmgren). ${ }^{3}$ This and another very similar species, both apparently endemic, may be known as Coelopencyrtus swezeyi and odyneri Timberlake.

In his supplement to the Hymenoptera of the Fauna Hawaiiensis, Vol. 2,Pt. 6, published nine years after the appearance of Ashmead's work, Dr. Perkins added nine species to the list; and in 1912 described Echthrogonatopus hawaiiensis as a new endemic species. ${ }^{4}$

During the following year, 1913, Mr. Fullaway described three new species from these Islands and records about five other unnamed species which had not been noted previously. ${ }^{5}$ In 1914 he recorded still another species taken on Laysan Island under the name of Ectroma species. ${ }^{6}$ This proves to be a Xanthoencyrtus, closely allied to two other species taken on Oahu, and will be described later as $X$. laysanensis. One of Fullaway's species, Apentelicus kotinskyi, proves to be the male of the species previously recorded under the name of Microterys flavus, and as there are slight but constant differences to separate it from Howard's species, it may be known hereafter as Microterys kotinskyi (Fullaway). It is possible that the true flavus is also established in the Islands, as I have seen a pair collected by Koebele on Hawaii. Mr. Fullaway also confused two species under his Aphycus terryi, one of which I have made the type of the genus, Pseudococcobius. His supposed male of terryi proves to be another species of Xanthoencyrtus which may be known as $X$. fullawayi Timberlake. With these corrections we find that twenty-five species of Encyrtidae have been recorded from the Islands up to the present time. In the last few years sereral other species have been collected or identified from earlier material so that now some forty-odd species are known to occur, or at least to have been collected here once, since the list includes two immigrant or

3 Hawaiian Sugar Planters' Experiment Station, Ent. Bull. 5, p. 52, pl. 6 , fig. 6 .

4 Hawaiian-Sugar Planters' Experiment Station, Ent. Bull. II, p. I7.

5 Ann. Rep. Hawaii Agric. Experiment Station, for I912, pp. 26-28; and Proc. Haw. Ent. Soc., Vol. 2, No. 5, p. 28I.

0 Proc. Hawaiian Ent. Soc., Vol. 3, No. I, p. 2 I. 
introduced species and possibly three or four which apparently failed to become established. ${ }^{7}$

\section{Sources of the Hawaina.i Encyrtidae.}

The family is represented in the endemic fauna by species belonging in at least five genera, of which Anagyrus Howard has about a dozen to fifteen species falling in a rather distinct group almost worthy of generic distinction. Xanthoencyrtus Ashmead has three or possibly more species, none of them having been hithertofore described and only one recorded under the name of Ectroma species. Echthrogonatopus Perkins has at least three species, E. hawaiiensis Perkins, E. molokaiensis (Ashmead) and one undescribed. The two remaining genera are represented by one or two species each, and are of unusual interest because of the structural peculiarities in the male sex. The first of these interesting and probably wholly endemic genera is Coelopencyrtus Timberlake with two species parasitic in the larvae of Odynerus, one of which as already stated Mr. Swezey has noted and figured under the name of Ageniaspis species. The other genus and species is Nesencyrtus kaalae (Ashmead), of which Dr. Williams has reared a large series from the larvae of Nesoprosopis pubescens Perkins taken from an old rotten $\log$ near the Volcano House at Kilauea,' Hawaii. in February, 1918.

The immigrant and introduced species belong in about twenty genera and have come mostly from the Oriental and Australian regions apparently, although at least three were introduced from North America, these being Helegonatopus pseudophanes Perkins, Saronotum americanum Perkins and Aphidencyrtus schizoneurae (Ashmead). Cameron's species Bothriencyrtus insularis is of uncertain origin although judging by the descripttion it seems to be an ally of Bothriencyrtus planiformis (Howard) of California, which is the type of this new genus.

7 These four species are Bothriencyrtus insularis (Cameron), Homalotylus flaminius (Dalman), Microterys flavus (Howard) and Comperiella bifasciata Howard. 
The following species are assumed to have come from the Oriental, Polynesian or Australian regions, judging from their known distribution, the range of their closest allies, or the distribution of their hosts or food-plants of the hosts. Blepyrus mexicanus Howard, although described originally from Mexico, Texas and the Hawaiian Islands, I have seen from Manila, Philippine Islands, and Mr. P. Van der Goot has informed me that it also occurs in Java. Its host, Pseudococcus virgatus (Cockerell) is known from Mauritius, Ceylon, India and the Philippine Islands and undoubtedly has a wide range throughout the Orient, whence it was probably introduced together with its parasite into the Hawaiian Islands as well as into the warmer parts of America.

Pauridia peregrina Timberlake, a somewhat close ally of Blepyrus, is the species recorded by Mr. Fullaway under the names of Anagyrus species and Encyrtus species parasitic on "Pseudococcus citri." I have studied specimens of this species collected at Amoy, China, by Mr. C. P. Clausen, in Fiji by Mr. Muir, in California by Mr. H. S. Smith, and have also seen the characteristic wing mounted on a slide with another Encyrtid from Manila, Philippine Islands. Its host, Pseudococcus krauhniae (Kuwana) ${ }^{8}$ was described from Japan and is presumably of Oriental origin. This parasite may have been brought in with its host from the Orient years ago, or possibly it was introduced from China by Compere in about 1908.

Tanaomastix abnormis (Girault) was first introduced and liberated in large numbers about Honolulu during the winter of 1915-1916, and additional colonies were turned out later. Its establishment was considered doubtful for a time because of the usual scarcity of its regular host, Pseudococcus krauhniae (Kuwana). Recently, however, it has shown its adaptability to local conditions, as Mr. Rosa has reared ' a few specimens

8 This is the species referred to in the literature on Hawaiian Coccidae as Pseudococcus citri, but I have recently discovered that our species is really $P$. krauhniae (Kuwana), in accordance with the distinctions brought out by Ferris (The California Species of Mealy Bugs, Stanford University Publications, University Series, 1918, p. 37, 45, pl. I, fig. 8): 
from Pseudococcus virgatus (Cockerell), collected in November, 1918, on the grounds of the Sugar Planters' Experiment Station. The species has thus become established from material received from California, whither it was brought originally from Sicily. It seems doubtful that the species is endemic in southern Europe, however, for its present known distribution is becoming cosmopolitan. Mr. J. R. Horton has informed me by word of mouth that the species occurred in Iouisiana before its introduction into California (the determination, I believe, being by Mr. Girault), and I have previously recorded the species from Okitsu, Japan. It is now my good fortune to be able to add.Brisbane, Queensland, to its known distribution, from specimens collected by the late E. J. Vosler. On the whole, therefore, I am inclined to believe in its Oriental, or possibly Australian origin, instead of South European.

Encyrtus infelix (Embleton) is now known to be widely distributed over the world and probably has followed its host, Saissetia hemisphaerica (Targioni Tozzetti), into most regions where the latter has penetrated. It would be impossible now to point out the original home of either the parasite or its host with exactitude, yet I believe this must have lain somewhere in the tropics of the Old World and probably in the Asiatic region. In addition to the localities recorded in the last number of our Proceedings from which I have seen this species, I have identified the species since from Rewa, Fiji (F. Muir); Brisbane, Queensland (E. J. Vosler); Tutuila, Samoa, near center of island (H. C. Kellers); and Manila, Philippine Islands (Geo. Compere).

A second species of Encyrtus, very closely allied to $E$. $b i$ color (Howard) but distinct in its much darker coloration and longer beard on the cheeks, has been present in the local collor for several years. This species, which may be known as Encyrtus barbatus Timberlake was collected in Honolulu by Alexander Craw in March, 1905, his speciurens having been reared from Saissetia hemisphaerica on ferns, and more 
recently Mr. Fullaway has reared a series from Saissetia nigra (Nietner) on ferns at Honolulu. Barbatus has been collected also by Mr. Muir at Pekalongan, Java, and on. Larat, and by Compere at Manila, so that it presumably was brought here from some part of the Oriental or Indo-Malayan region.

In the collection of the Board of Agriculture and Forestry there is a single specimen of Homalotylus flaminius (Dalman) collected years ago on the Island of Oahu by Koebele. In a revision of the species of Homalotylus, which I hope will be published soon in the Proceedings of the U..S. National Museum, I have referred all forms of the flaminius type from Europe, Africa, Asia, and Australia to one species, to which our local specimen belongs rather than to the North American species. It is therefore likely that the species was an accidental introduction from the Orient or Australia, and as it has not been found in recent years it apparently failed to become established.

Quaylea aliena Timberlake is another species which I believe originated in the Old World and possibly in Australia. It is very closely related to a species common in California which has been described recently by Mr. Girault as Cerchysius whittieri and which is the type of my new genus Quaylea. Quaylea whittieri is the same species, I am almost positive, which Ashmead called Hemencyrtus crawii but did not describe, although it has been mentioned in the literature several times under that name by Isaac, Berlese and Silvestri; and under the name of Cerchysius species by Prof. H. J. Quayle and myself. If, as I suppose, it is the Hemencyrtus crawii mentioned by Berlese and other writers it was purposely introduced into California from Australia as a parasite of the black scale, Saissetia oleae (Bernard), although it has since proved to be a hyperparasite. Our local species, being closely allied and having the same habits, probably also came from Australia or some part of the Orient. It was recorded by Fullaway in 1913 as Hemencyrtus species, and possibly also under the name of Encyrtus species on Saissetia hemisphaerica and Coccus 
viridis (Green). It has been reared at Honolulu from several Coccids as a parasite of Scutellista cyanea Motschulsky and Tomocera californica Howard.

Among our immigrant Encyrtids are two species of $A p h y$ cus which have escaped being recorded hithertofore. The most common species is Aphycus alberti Howard, which was described from Sydney, New South Wales, and has since been recorded from Southern California. As it is parasitic in the widely distributed Coccus hesperidum Linné, and in closely allied species, it presumably has a much wider distribution than is known at present, and its place of origin will hardly ever be determined exactly. Without much question, however, it originated somewhere in the warmer regions of the Old World and not necessarily in Australia, whither it may have been introduced as well as into these Islands and California. Alberti has been found here only recently, as apparently the first specimen was reared by Mr. Swezey from Coccus longulus (Douglas) on velvet bean from the Experiment Station grounds in October, 1914. The other species is Aphycus claviger Timberlake, described from Auckland, New Zealand: Nothing is known of the habits of this species but as it is a close ally of alberti it may have similar habits. The local record is based on a pair of specimens collected by the writer on a side spur of the main ridge leading up to Mt. Lanihuli: Oahu, on September 3, 1916. Three specimens were seen running about on a slender withe of a species of Kadua, one of which leaped away before it could be captured. The Kadua twig and surrounding shrubbery were carefully eramined for the host of these parasites, but no coccids of any kind were discovered.

Microterys kotinskyi (Fullaway) and M. flavus (Howard) are species of almost certain Oriental origin. Kotinskyi is very closely allied to flavus which has been recorded from Ceylon and which I have seen also from Japan, as well as other species nearly identical from Fiji and the Philippine Islands. Our collections of Microterys from those parts of the world, 
however, are much too meager to shed much light on the distribution, interrelationships and possible intergradations of the species or forms allied to flavus.

Aphycomorpha araucariae Timberlake was reared first in July, 1906, by Mr. Kotinsky from Eriococcus araucariae Maskell collected on the grounds of the Board of Agriculture and Forestry at Honolulu, his rearing being represented by four broken specimens. More recently Mr. Fullaway has reared a small series from the same locality and host, and I obtained a few specimens from the Moanalua Gardens in May, 1918. As the host and food-plant of the host in this case are both of Australian or New Zealand origin there can be but little doubt that the parasite also was derived from that part of the world

Comperiella bifasciata. Howard was introduced at Honolulu in 1908 from the Orient, presumably from China, as noted by Kotinsky in the Hawaiian Forester and Agriculturist, Vol. 5, p. 148, July, 1908. A single specimen, however, was reared before that time in August, 1905, by Kotinsky from an Aspidiotus on Bombax ceiba. The species has never been taken since and its establishment here is therefore doubtful. It was recorded by Fullaway as Cerapterocerus species on Aspidiotus.

Anicetus annulatus Timberlake has been established in the Islands apparently for a considerable period of years, as it is widely distributed on Oahu and Kauai. It is nevertheless rarely taken and the specimens in the local collections are few in number. The earliest specimen that $I$ have seen was reared by Mr. Fullaway, April 25, 1912, supposedly from Saissetia hemisphaerica (Targ.), but thïs host record is probably incorrect as all the subsequent reared specimens have come from Eucalymnatus tessellatus (Signoret). I hardly question the Oriental origin of annulatus although no specimens from that part of the world have come to hand. The genus, moreover; seems to have originated in the warmer parts of the Old World. as the three species described previously by Howard and Girault were collected in Ceylon, China and Queensland respectively. 
There are also two species of Encyrtidae parasitic on Pseudococcus saccharifolii (Green) in the Islands, which were almost unquestionably brought in with their host. Neither of these parasites have been found elsewhere, but as their host has a known distribution in India it seems likely that both Coccid and parasites were introduced in importations of sugarcane from some part of the Orient. The more abundant one of these parasites, Pseudococcobius terryi (Fullaway), has been found on Hawaii, Maui and Oahu and probably occurs on Kauai, as it is apparently distributed throughout the Islands wherever its host is found. The other parasite, Xanthoencyrtus fullawayi Timberlake, is much rarer, and I have seen only two female specimens. One of these, which may have been the type of Fullaway's description of the supposed male of terryi, was found in a vial without data together with specimens of terryi. The second specimen was reared from material of its host collected by Mr. Swezey in August, 1916. at Pahala, Hawaii.

Adelencyrtus odonaspidis Fullaway is a species of which we have no direct clew as to its place of origin. Its host, Odonaspis ruthae Kotinsky, has not been found elsewhere, but its food-plant, Cynodon dactylon, is known to be iridigenous in the warmer parts of Europe and Asia although now spread throughout the world. It is quite possible, therefore, that both host and parasite may some time be traced back to some part of the Orient, although they may have reached the Islands from some intermediate station.

Concerning the origin of at least two other species of our Encyrtidae we have as yet even less knowledge. Anagyrus, which is represented in the endemic fauna, has also one or possibly two, introduced species. One of these, the large brown species with black antennae, which may be known as Anagyrus nigricomis Timberlake, does not seem to have been recorded hithertofore. It is widely spread on Oahu in both the lowlands and mountains, and I have seen specimens from Kauai. It has therefore been in the Islands for a considerable number of 
years, although the earliest specimen I have seen was taken by Mr. Swezey as late as March, 1910. The species undoubtedly has a wide range of hosts, and probably parasitizes many of our endemic species of mealy bugs. I have reared it from Pseudococcus gallicola and montanus Ehrhorn, and have found it associated with Trionymus insularis Ehrhorn. I have also reared it experimentally from the introduced Pseudococcus longispinus (Targioni Tozzetti) and $P$. lounsburyi Brain, and in the Board of Agriculture and Forestry collection is a series of specimens reared by Mr. L. V. Lewis from Ripersia palmarum Ehrhorn. Perkins in his supplement to the Hymenoptera of the Fauna Hawaiiensis claims that one or two species of Anagyrus were introduced by Koebele but gives no particulars as to the time of introduction or the source of the material. Nigricornis, therefore, possibly may have been introduced by Koebele although we have no definite proof in the shape of preserved material or written records. I have seen a similar, closely allied species collected by Mr. Muir in Fiji, which is the only clew to the origin of nigricornis that $I$ can suggest

In 1913 Mr. Fullaway recorded another species of Anagyrus as Encyrtus species with banded antennae which I have named Anagyrus swezeyi. His host record, however, is incorrect, as this species is parasitic only in Trionymus insularis Ehrhorn so far as known, and there is no possibility of its being parasitic in Saissetia. This parasite is common through the lowlands of Oahu, and I have seen specimens from Lihue, Kauai, and Lupe Ditch, Maui. Most likely it is present also on the other large Islands, as no effort has been made to discover its distribution outside of Oahu. I am inclined to believe that it has been present in the Islands for many years and it may possibly be endemic since it is much more closely allied to the unquestionably endemic species of Anagyrus than is nigricornis, and resembles them in many particulars. 


\section{Means of Introduction of Immigrant Species of} ENCYRTIDAE.

There are published records of the intentional introduction of only two of our Hawaiian Encyrtidae, namely Tanaomastix abnormis (Girault) and Comperiella bifasciata Howard, the latter of which was found here before its liberation but has not been seen since. The introduction of Paracopidosomopsis truncatella (Dalman), and a Chalcaspis species has been reported upon also by Koebele and Craw, but neither of these parasites has been recovered. It is probable that Anagyrus nigricornis Timberlake was introduced by Koebele, and Pauridia peregrina Timberlake may have been brought from China by Compere although we have no definite information on these introductions. As far as we actually know none of our other Encyrtids was intentionally introduced, and probably most of them arrived in importations of plants before the days of strict quarantine. Aphidencyrtus schizoneurae (Ashmead) might have been brought in importations of cabbage or other vegetables from California, and in fact Mr. Fullaway has informed me that several of our Aphidid parasites and hyperparasites were intentionally allowed to escape from material received here in such a manner. Two others of our Encyrtidae, Helegonatopus pseudophanes Perkins and Saronotum americanum Perkins, which are parasites of Dryinidae, were probably either accidentally or perhaps intentionally liberated, through ignorance of their true nature, from material sent to Honolulu from Ohio by Koebele in 1903. They are both known to have been reared at Honolulu from the Ohio material, and as they appeared in the cane fields a few years later it seems probable that they were introduced at that time.

\section{Aids in the Establishment of Immigrant Specins of Encratidae.}

When an emigrant species of parasite reaches a new region it is of course a prerequisite for its establishment that it finds its customary host or one related closely erough to act as a substitute. All Encyrtidae so far as known are internal 
parasites, ${ }^{9}$ and some are notable for the peculiar adaptations to their host during their larval life. The habits of species throughout the whole family may in fact be considered highly specialized in regard to their host relationships. : Many species indeed so. far as we know seem to be confined exclusively to one species of host and may be called monoxenotic in habit. Others are known to attack and successfully parasitize two or more species of hosts generally belonging to the same or elosely allied genera, and these parasites may be cited conveniently as polyxenotic in habit.

Among our immigrant species of Encyrtidae we know rather definitely that Adelencyrtus odonaspidis, Anagyrus swezeyi, A phycomorpha araucariae, Blepyrus mexicanus, Pauridia peregrina, Pseudococcobius terryi and Xanthoencyrtus fullawayi are all monoxenotic. With the possible exception of Pauridia peregrina all of these species were introduced quite likely concurrently with their hosts, either at the first or subsequent arrivals of the latter in the Islands, and their establishment here was on that account more easily accomplished.

Anagyrus nigricornis, Aphidencyrtus schizoneurae, Aphycus alberti, Comperiella bifasciata, Encyrtus infelix and barbatus, Helegonatopus pseudophanes; Microterys kotinskyi, Quaylea aliena, Saronotum americanum and Tanaumastix abnormis are apparently all polyxenotic in habit. The establishment of such of these as were purposely introduced undoubtedly was aided by this habit, and this was true probably of most of the other species. Some of them presumably were brought in concurrently with the host or hosts which they now attack, but this is not necessarily true of all, and in fact can not possibly be true of some:

Peculiarities in the life-history and habits of parasites may also play a large part in aiding or hindering their introduction and establishment in a new environment. Thus Pauridia peregrina and Blepyrus mexicamus are known to deposit their eggs

- The only exception is Aphycus hesperidum which Mercet claims is an external parasite of Chrysomphalus dictyospermi var. finnulifer, but I am strongly inclined to believe that the record is based on an error of observation. 
in newly hatched larvae of their hosts, and Blepyrus indeed apparently never attacks the later stages although issuing from nearly full-grown hosts. It is at once obvious that Coccids in their earlier stages might more easily escape the attention of the careful plant-grower or importer and thus be allowed to become established in a now locality. If some are parasitized the establishment of both host and parsite is thus accomplished at the same time.

Parthenogenesis has also played a large part without much doubt in helping the establishment of certain of our immigrant species. As a general rule it may be stated quite confidently that all Encyrtidae, and for that matter most if not all Chalcidoidea, in so far as their habits have been investigaied, are able to reproduce parthenogenetically under stress of necessity. -Probably most species of Encyrtidae produce only males when the reproduction is parthenogenetic, and in case of the usual method of reproduction they produce in different species a variable proportion of both males and females. Before studying the habits of our local species $I$ had never verified the existence of any other method of reproduction among the Encyrtidae, and was surprised to find that certain of our species are regularly thelyotokous in reproduction. In Adelencyrtus odonaspidis, Blepyrus mexicanus, Encyrtus infelix, Pauridia peregina and Saronotum americanum thelyotoky is the regular means of reproduction and males are rarely produced, being in fact entirely unknown in case of Adelencyrtus and Saronotum. I have reared the Pauridia through many generations without finding any males, and have in fact seen but a single male reared by $\mathrm{Mr}$. ${ }^{\circ}$ Ehrhorn several years ago. I have likewise reared Blepyrus through several generations and was able to find males of this species only by examining some bean vines at the Sugar Planters' Experiment Station at a time when both host and parasite were unusually abundant. Of Encyrtus infelix I was fortunate enough to rear a single male in a small series obtained in 1916, and this is the only male specimen that $I$ have seen out of numerous specimens examined from various parts of the. world. Miss Embleton in her work 
on this species states that the males are excessively rare, only one occurring to about a thousand females. The existence of this habit of thelyotoky is obviously a great advantage to a species invading a new region, since it might become established under favorable conditions from a few females or even from a single specimen. Conversely the arrhenotokous habit of reproduction may act disadvantageously before a species is well established, since the rapid dispersal which usually takes place will tend to increase the difficulties of the sexes finding each other, and thus restrict the necessary fertilization of the females.

In conclusion we may summarize our knowledge of the local Encyrtid fauna somewhat as follows: The endemic fauna is represented by five genera with about twenty to twenty-five species. Eighteen genera of introduced Encyrtidae have been recognized already, with two or three species as yet unworked which may raise the number of genera to about twenty. The source of three species is undoubtedly North American, and the rest of the immigrant species presumably have arrived mostly from the Australian, Polynesian or Oriental regions, although we have no very definite clews to the origin of several. At least two and possibly four species having been collected years ago but not recovered since are probably extinct in the Islands. Only two species are definitely known to have been introduced intentionally, although several others may have been as the records of early introductions are fragmentary. About seven of the immigrant species are monoxenotic and eleven others are polyxenotic, the former having been introduced presumably concurrently with their hosts, the latter not necessarily so. Peculiarities in the habits and life history have had some influence on the introduction and estallishment of the Hawaiian Encyrtidae, since oviposition in the earlier stages of the host, thelyotokous reproduction and the polyxenotic habits of certain species are obviously advantageous in the dispersal of the species into new regions. 